\title{
Environmental disclosure in the Brazilian electricity sector
}

\section{Célia Braga*}

Faculty of Economics, Business Administration and Accounting, University of Ceará,

Av. da Universidade, 2431,

Benfica, 60020-180, Fortaleza, Ceará, Brazil

and

INESC-Coimbra,

Rua Antero de Quental,

199, 3030-030 Coimbra, Portugal

E-mail: celiabc@fortalnet.com.br

${ }^{*}$ Corresponding author

\section{Patrícia Pereira da Silva}

Faculty of Economics,

University of Coimbra,

Av. Dias da Silva,

165, 3004-512 Coimbra, Portugal

and

INESC Coimbra,

Rua Antero de Quental,

199, 3030-030 Coimbra, Portugal

E-mail: patsilva@fe.uc.pt

\section{Ariovaldo dos Santos}

Faculty of Economics and Administration,

University of São Paulo,

Av. Prof. Luciano Gualberto,

908, Butantã, 05508-010, São Paulo, Brazil

E-mail: arisanto@usp.br

\begin{abstract}
This study aims to analyse the importance of the disclosure of ANEEL's social and environmental report to the Level of Disclosure of Environmental Information of Brazilian companies in the electricity sector in the period from 2006 to 2009 . The analysis was focused on 60 companies dedicated to various activities in the value chain of the electricity industry. The metric totals 90 indicators, including 34 from the global reporting initiative (GRI) and 56 from the National Agency of Electrical Energy. In this research content analysis and correspondence analysis in panel were the used techniques, respectively. As data collection and analysis technique, the research
\end{abstract}


used content analysis and correspondence analysis in panel techniques, respectively. Results showed a significant evolution in the disclosure level of the entities under study, as a result of ANEEL's social and environmental report disclosure. Despite the growth in the voluntary disclosure of the GRI model, it does not reach the level of disclosure resulting from the Brazilian regulatory agency's guideline.

Keywords: environmental indicators; environmental disclosure; electricity; GRI; global reporting initiative; ANEEL report.

Reference to this paper should be made as follows: Braga, C., da Silva, P.P. and dos Santos, A. (2014) 'Environmental disclosure in the Brazilian electricity sector', Int. J. Innovation and Sustainable Development, Vol. 8, No. 1, pp.37-52.

Biographical notes: Célia Braga is a Professor in the Accounting Department at Federal University of Ceará. She has a Masters Degree in Accounting with emphasis in Controllership from the University of Sao Paulo, a $\mathrm{PhD}$ in Business Administration from the Faculty of Economics at the University of Coimbra, she is a fellow of the Coordination for Higher Education Personnel Development (CAPES) and a researcher at the Institute of Systems and Computer Engineering (INESC-Coimbra).

Patrícia Pereira da Silva holds a PhD in Finance and a Masters Degree in Business Administration from the University of Coimbra. She is an Assistant Professor at $\mathrm{PhD}$ level in Sustainable Energy Systems (MIT-Portugal Program). Her research interests, conducted at INESCC, are in the areas of energy economics, energy finance and markets, and sustainable energy systems.

Ariovaldo dos Santos is a Professor at the Faculty of Economics, Management and Accounting - University of São Paulo (FEA-USP). He holds a Masters degree, a $\mathrm{PhD}$ and he is Professor at FEA-USP, fellow in the Productivity and Research of CNPq in the period 2005-2011, a researcher at the Research Institute of Accounting, Actuarial and Financial - FIPECAFI and technical coordinator of Melhores e Maiores Magazine from Abril Publisher.

\section{Introduction}

The great challenge for companies from the electricity sector in the 21 st century is to provide a tripod to ensure the supply of electricity to a growing consumer market, with low emission of greenhouse gases through clean energy sources, at a fair price for consumers and to guarantee economic and financial returns for companies.

In this context, to monitor the environmental and economic aspect synergistically, electricity companies in Brazil use certifications, management models and international and national guidelines for voluntary disclosure of environmental performance.

The international orientation of global reporting initiative (GRI) has indicators that address the economic, social and environmental aspects and a group of specific indicators for the electricity sector. The regulator for this sector in Brazil, the National Agency of Electrical Energy (ANEEL), created a set of specific guidelines for the Brazilian segment aiming at developing the social and environmental report, which increased environmental disclosure in the Brazilian electric sector. 
Therefore, this study aims to analyse the importance of the disclosure of ANEEL's social and environmental report to the environmental information disclosure level (EIDL) of Brazilian companies in the electricity sector in the period from 2006 to 2009.

Voluntary disclosure is studied based on the Accounting Theory, whose aspects of qualities and elements of accounting information are integrated in the conceptual framework of the Financial Accounting Standard Board (FASB) and associated with the International Accounting Standard (IAS) developed by the International Accounting Committee Standard (IASC). The most important element of such framework is the user of the accounting information, which in this investigation will be the priority stakeholders of the social and environmental information disclosed in the GRI report and studied from the standpoint of Stakeholders Theory.

The study has three objectives: the first is to descriptively analyse the sample, the second is to evaluate the evolution in the EIDL in the sample and the third is to verify the relationship between the EIDL and the year of the disclosure, applying correspondence analysis (CA).

The study is structured in five sections. The next section deals with the previous studies that address the disclosure of environmental information and the sustainability report. The third describes methodology and sample identification. The fourth section presents the analysis of results, and the fifth is the conclusion.

\section{Disclosure of environmental information and sustainability report: review of literature}

The conceptual framework of the International Accounting Standard Committee (IASC) and the FASB are used to financial disclosure by companies all over the world today. Among the scope elements, these should be highlighted: the objectives of financial statements and the qualitative characteristics that determine the usefulness of the information contained in those statements (Ernst \& Young and FIPECAFI, 2009; Riahi-Belkaoui, 2004).

Even though the FASB and the IASC have not yet presented standards on the social and environmental aspects, its conceptual basis is applicable to these dimensions. The complexity of the publication of such information, as well as financial information, is related to the quality of the information provided and the conflict of interest it presents to the company, other stakeholders and to accounting professionals, including auditors (Riahi-Belkaoui, 2004; FASB, 1980).

In 1990s, the evolution of Cost and Management Accounting (Horngren et al., 2000) and studies on corporate social responsibility (CSR) expanded research on Accounting for Sustainability, which aims to promote a sustainability strategy and acts as an extension of cost, financial or management accounting. This accounting allows an assessment of the risks and benefits of social, environmental and economic aspects for the company's management and external stakeholders (Schaltegger and Burritt, 2009; Freeman and Reed, 1983; Sangle and Babu, 2007).

Studies on environmental disclosure are present in several countries (Monteiro and Aibar-Guzmán, 2010; Skouloudis et al., 2010, Aerts and Cormier, 2009; Liu and Anbumozhi, 2009; Simnett et al., 2009; García-Sánchez, 2008; Cho and Patten, 2007; Brammer and Pavelin, 2006; Campbell, 2004, Cormier and Magnan, 2003; García-Ayuso and Larrinaga, 2003, Holland and Boo Foo, 2003; Moneva and Llena, 2000). The 
research by Múrcia et al. (2008) in 77 studies on environmental disclosure in the period from 1997 to 2007 shows that there is a concentration of research in the UK, USA, Canada, Australia and New Zealand. In Brazil, there is still lack of research in this area.

Owing to the importance of environmental information to external stakeholders, comparability becomes an essential element in making decisions that require the monitoring of past (Traditional Financial Accounting), present (Management Accounting) and future (Comptroller) results. The comparison allows analysing the evolution of the company and its performance in relation to companies in the same sector and different sectors (Hendriksen and Van Breda, 1992). Sustainability Accounting allows this analysis to the environmental dimension of information.

In order for stakeholders to evaluate the company's environmental performance there must be disclosure that comprise qualitative and quantitative information, it must be presented in monetary and non-monetary data format, in the course of time and with the indicative targets. The disclosure report, although voluntary, must:

- $\quad$ include minimum standards - GRI and ANEEL guidelines

- be published following a schedule consistent with the objectives of the stakeholders - the most common pattern is the annual financial disclosure consistent with, but not necessarily published on, the same date

- $\quad$ have an easily accessible support - currently, the most common is the internet, with disclosure on the homepage of the company (ETHOS - Instituto Ethos, 2010; Bolívar, 2009).

According to Jose and Lee (2007), the internet has emerged as a low-cost, quick and easy-to-access tool.

In Brazil, the internet is widely used by public companies (Calixto et al., 2007; Rover et al., 2009). In the companies' homepages it is possible to find environmental reports more efficiently, as the internet allows the company to disclose the report and several types of information according to the needs of each user - extension, model and language (Bolívar, 2009). In addition to the disclosures in site, companies still use the report printed in full or a summarised version.

Some solutions presented by non-governmental organisations (NGOs) are aimed at alleviating the problem of lack of standardisation and uniformity in the content of environmental reports and the lack of reliability (Simnett et al., 2009). The most recommended is the auditing, but the cost of the service has driven companies to external certifications such as the International Standards Organisation's (ISO) 14001, which promotes the standardisation of environmental practices and their disclosure.

It is also important to highlight the following international initiatives: global reporting initiative (GRI), coalition for environmentally responsible economics (CERES), public environmental reporting initiative (PERI) e International Chamber of Commerce Business Charter for Sustainable Development (ICC) (Jose and Lee, 2007). In Brazil, in addition to ANEEL guidelines noteworthy are the Brazilian Institute of Social and Economic Analyses (IBASE) and Ethos Institute guidelines.

In this study, we analyse the publications of the sustainability report using the GRI indicators, G3, and the social and environmental report indicators with ANEEL's guidelines. 


\section{Methodology and sample identification}

The survey was conducted in the electricity sector in Brazil, using the financial year of 2008 as the base period for the sample definition as the benchmark considered in the study is the regulation of social and environmental release of ANEEL's report, which came to be published by all companies in this exercise.

The period defined for the study covers the years 2006-2009 to allow the evaluation of the impact of ANEEL's resolution on the level of disclosure of environmental information. To do that, we examined the year 2006, when companies performed only voluntary disclosure of GRI indicators. The following year, 2007, in which only the distributors released ANEEL's report and the years 2008 and 2009, in which companies of all activities were directed to undertake the publication as stated on Resolution No. 3034, of 12.21.2006.

The sample was identified from the universe of companies (120) that disclosed the reports with ANEEL environmental indicators in 2008. The universe analysed included the 11 companies that disclosed the GRI environmental indicators, see Table 1.

The sample selection was carried out based on the disclosure of environmental information reports published on the GRI and ANEEL websites, see Table 2.

Table 1 Number of reports published and sample definition

\begin{tabular}{lccc}
\hline & \multicolumn{2}{c}{2008} & \\
\cline { 2 - 4 } Companies & $G R I$ & ANEEL & Sample size \\
\hline Generation & 5 & 25 & 15 \\
Transmission & 1 & 34 & 5 \\
Distribution & 5 & 61 & 40 \\
Total & 11 & 120 & 60 \\
\hline
\end{tabular}

Source: ANEEL (2010) and GRI (2010)

After analysing the indicators, the sample defined was 60 companies from the operational value chain of the sector (see Table 2). The energy sector also has holdings and trading companies which were not addressed. The reason is that the trading companies lack direct environmental impacts, and the holdings do not release information on a consolidated basis.

The research uses the technique of content analysis combined with documentary research, as in Bardin (2008), to analyse the environmental indicators of sustainability reports (GRI and ANEEL) and calculate the EIDL index.

The metric was structured with 34 indicators from the GRI guidelines and 56 indicators from ANEEL, totalling 90 environmental indicators. Previous studies by Liu and Anbumozhi (2009), and Jose and Lee (2007) provide the general framework metrics. Additionally, findings by Skouloudis et al. (2010), Liu and Anbumozhi (2009), Brown et al. (2009), Panayiotou et al. (2009), Gallego (2006) and Morhardt et al. (2006) allowed us to account for GRI indicators in the metric. The investigation outlines a metric of 34 environmental indicators (18 essential indicators, 11 additional and 5 specific). 
The ANEEL indicators are classified in categories: recovery of degraded areas; waste generation and treatment; use of resources in productive and management processes; environmental education and awareness; environmental research and development; culture, sport and tourism and health.

Table 2 Sample of the Brazilian enterprises, level of disclosure of environmental information

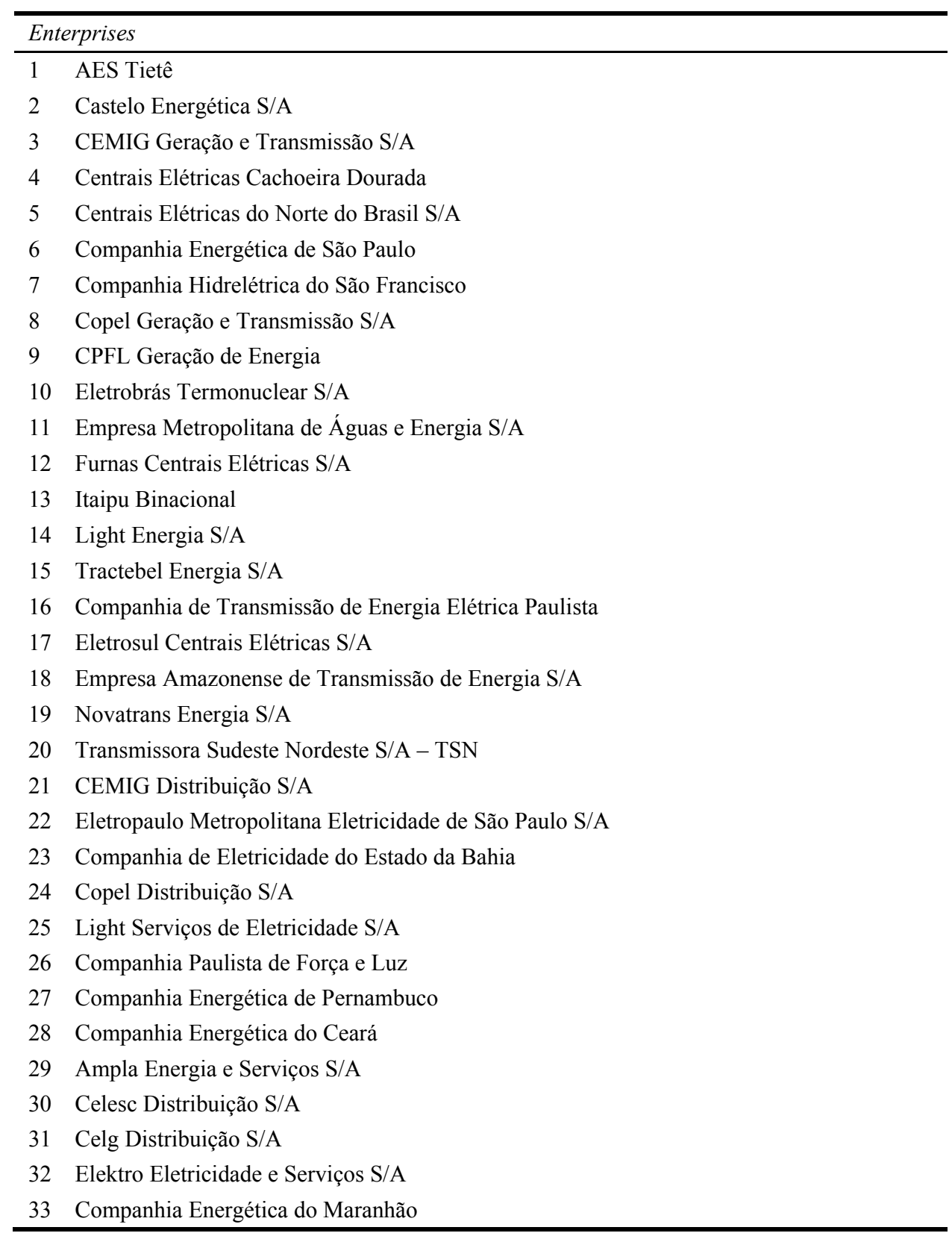


Table 2 Sample of the Brazilian enterprises, level of disclosure of environmental information (continued)

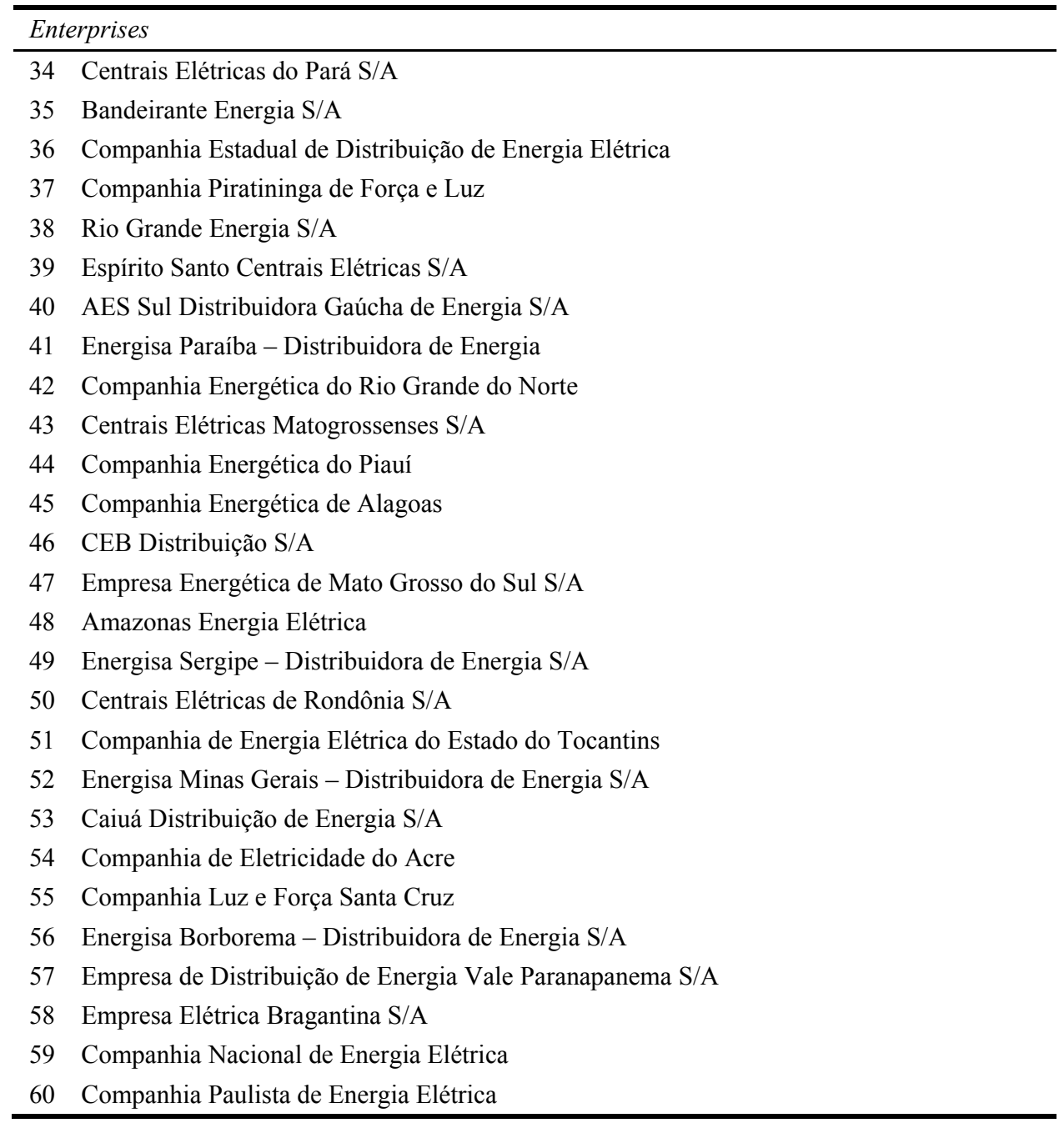

Source: Prepared by the authors based on ANEEL (2010) and GRI (2010)

Several approaches are possible when developing a scoring scheme to determine the level of disclosure in annual reports, and traditionally both a weighted disclosure index and an unweighted disclosure index have been used by researchers. Those such as Hossain and Hammami (2009), and Cho and Patten (2007) adopted dichotomous procedures in which an item scores one if disclosed and zero if not disclosed and this approach is conventionally termed the unweighted approach. This study adopted such dichotomous procedures. 
The method for calculating the disclosure score of each company can be expressed according to equation (1) (Hossain and Hammami, 2009).

$$
\mathrm{EIDL}=\sum_{j=1} \frac{d_{j}}{n},
$$

where EIDL is the aggregate disclosure score; $d_{j}: 1$ if the $j$ th item is disclosed or 0 if it is not disclosed; and $n$ : the maximum score each company can obtain. In this case, the key factor is whether or not a company discloses an item of information in the annual report.

The EIDL index of each company was calculated by adding individual scores and then dividing the result by the total maximum score that could be obtained in each case, i.e., 90 points.

To qualify companies on their disclosure level, the criterion adopted was to divide the level of disclosure in quartiles to distribute the EIDL variable classified in four categories of level of disclosure: poor, fair, good or excellent.

To test the reliability of the metric, we used Cronbach's alpha, which showed as a result 0.963, ranked as a very good internal consistency (Pestana and Gageiro, 2008; Maroco and Garcia-Marques, 2006; Hair et al., 2005; Churchill, 1986).

The research uses the philosophical concept of sustainable development established by the United Nations, in the Brundtland Report (United Nations, 1987).

To evaluate the relationship between the EIDL variables and the years of dissemination of environmental information a technique called correspondence analysis (CA) was used, in panel, with 240 pieces of information (Hair et al., 2005).

\section{Results}

The results are presented in two steps. The first one deals with a descriptive and qualitative analysis of the sample. The second one presents the evaluation from the CA.

Figure 1 shows the number of companies in the sector that reported the GRI and ANEEL indicators during the study. By analysing the years 2008 and 2009 it is possible to notice the large number of publications of ANEEL, compared with the GRI disclosure. This indicates a strong influence of the regulatory agency in the promotion of social and environmental information disclosure, although it is not mandatory.

The reduction in the number of companies in 2009 may be due to the fact that data collection was held in October/2010, when not all companies had yet reported on the GRI and ANEEL website. The date, used in an arbitrary way, is justified by the extensive amount of data that had to be collected to form the database. Clarkson et al. (2008) used this temporal feature.

Concerning the publication of the sustainability report with the disclosure of GRI indicators of the sample, Figure 2 shows that 34 publications were used in the period 2006-2009.

It is a small number of publications and it is concentrated only in large and publicly traded companies. The high number of firms (206) which did not publish the international model of sustainability report contributed to the low level of disclosure, particularly for producing and transporting energy companies. 
Figure 1 Published reports, GRI and ANEEL, 2006-2009

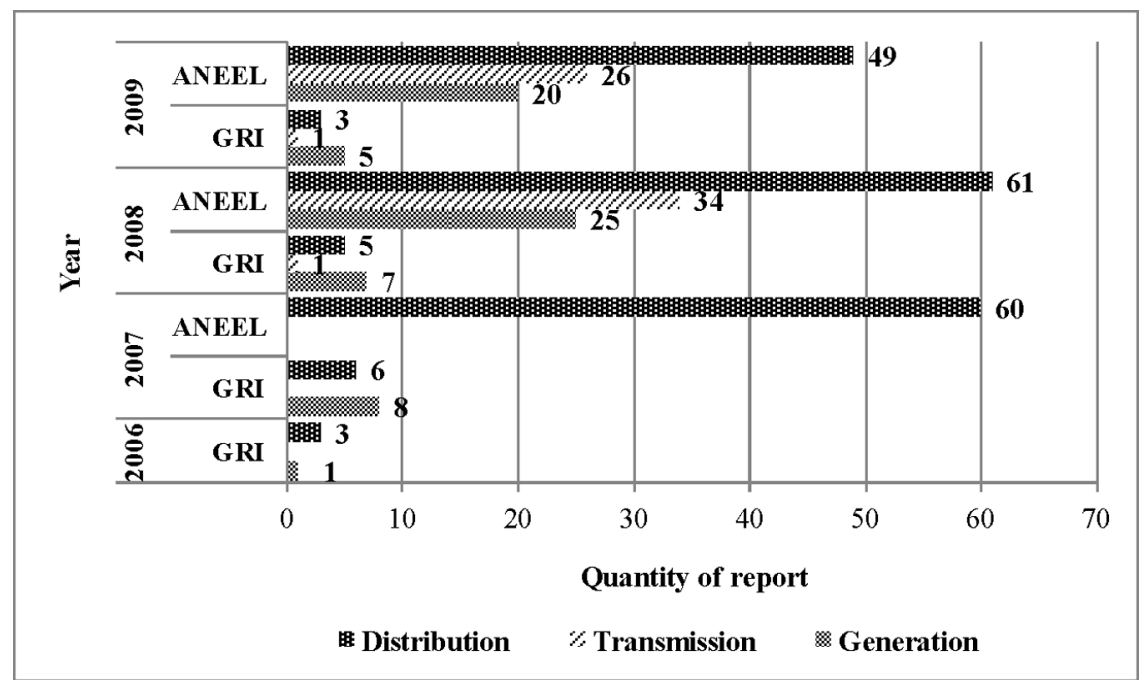

Source: GRI (2010) and ANEEL (2010)

Figure 2 Disclosure reports of the sample, GRI and ANEEL, 2006-2009

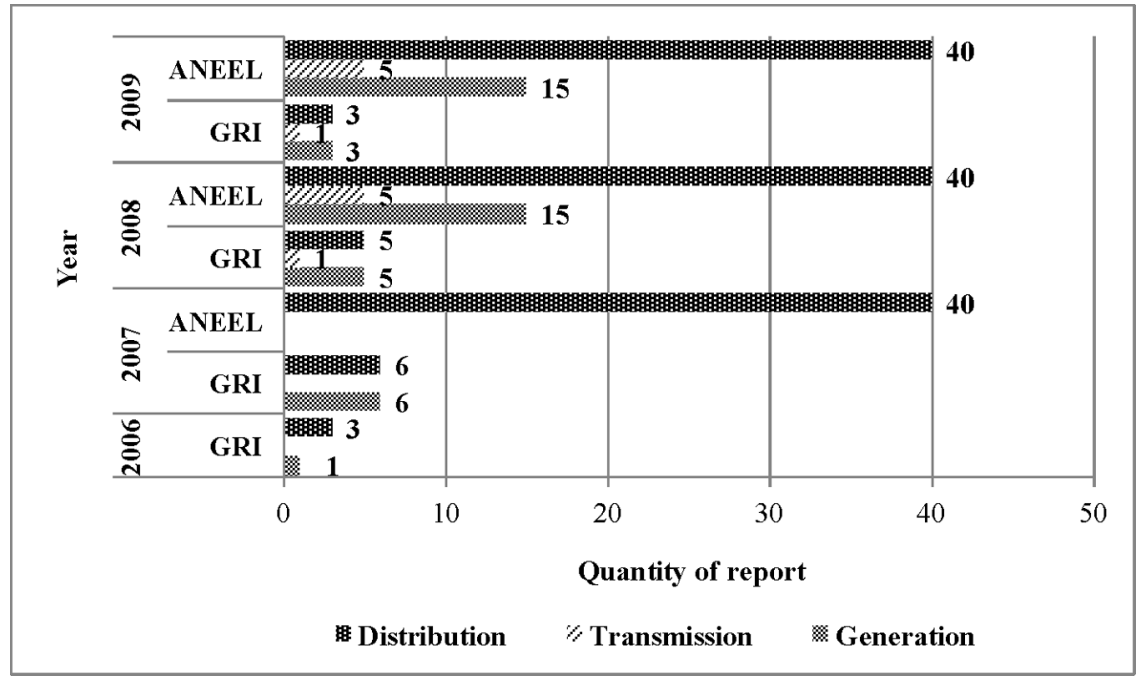

Source: Prepared by the authors based on GRI (2010) and ANEEL (2010)

The first publication of the social and environmental ANEEL report highlights the importance of disclosure from the distributors, with more than 500,000 consumers; these are classified as large companies, and participate in sustainability indexes and in national and international stock markets.

The analysis of the most published and the least published indicators of the sample, not considering the companies that did not publish, shows that there is little difference in the analysis without them. By evaluating the unpublished ANEEL indicators, in the period 2006-2009, with missing, of at least 50\% of the sample (80 pieces of information), we noted that the worst performances for the indicators are the A39 (147), 
A2 (132), A11 (131), A19 (130) and A55 (127) indicators. This category includes 33 indicators.

In terms of the most published indicators for at least $50 \%$ of the sample, it is possible to note that the best performances are the A37 (133), A28 (130), A30 (127), A38 (125) and A34 (123) indicators. Twenty-three indicators are in the most published category.

The total number of indicators is $13,440,5520$ of which are classified as the most published and 7920 as the least published.

As for the GRI indicators, the least published by at least $50 \%$ of the sample (80), are EN25 (32), EU5 (29), EU13 (28) and EN15 (27). The less disclosed categories of indicators are the additional (6) and the sectoral (4) categories. And the most widespread is the key indicators (14) category.

The most published indicators are SO1 (33), EN30 (31), EN26 (30), EU1, EN8 (29), EN3 and EN14 (28). The number of published indicators (20) is greater than the number of unpublished indicators (14). During the period of study, the total of the most published indicators reached 4,800 and the least published was 3360 .

Table 3 presents a summary of the total of indicators $(21,600)$. Noteworthy are the least published in the ANEEL and the most published in the GRI. The result shows that despite the positive developments in the period, the sector still needs to improve the quality and quantity of published indicators.

Table 3 Summary of the most and the least published indicators, with missing, 2006-2009

\begin{tabular}{lrcc}
\hline Indicators & ANEEL & GRI & Total \\
\hline Most published & 5.520 & 4.800 & 10.320 \\
Least published & 7.920 & 3.360 & 11.280 \\
Total & 13.440 & 8.160 & 21.600 \\
\hline
\end{tabular}

Source: Prepared by the authors

As for the qualitative and quantitative analysis (monetary and non-monetary) of the information published in the reports, there is a positive development, but it does not meet the uniformity of disclosure of environmental information, notably the ANEEL report because many companies publish results with zero values or the acronyms that mean Not Available (ND), Not Identified (NI), Not Applicable (NA) and Unpublished (NP). The information that allows comparability also evolved, including the information on goals, but is still hampered by the absence of information.

In its first periods of publication, ANEEL's social and environmental report is presented as essentially quantitative, in the environmental aspect. The report generally presents the indicators responses in a table format, and in the dimension context section the subject is treated very briefly without any strategic context of the company's business and the interests of stakeholders. This aspect needs to be improved.

Companies sought to follow the GRI guidelines in its form, but the lack of obligation undermines uniformity as a quality of the information. The reports present a summary table of interaction between the GRI indicators and the Global Agreement principles, but there are cases where the page numbers indicated do not refer to the correct location of the indicator response. Only a few companies make the identification of the indicator in the text. The companies from Companhia Paulista Força e Luz (CPFL) groups, 
Companhia Energética de Minas Gerais (CEMIG), Endesa and Energias do Brasil have the best level of disclosure.

Another important element in the decision-making is the process of communication and the media. That is to say, defining how information will be published. The following media are identified in the Brazilian electric sector: printed report and/or webpage publication, complete, summarised and/or folder, DVD and/or flash drive, specialised magazines and/or awards.

In the second analysis, the disclosure shows that in 2006, the lowest level of disclosure was zero and the highest was 0.2111. In 2007, the minimum EIDL was zero and the maximum was 0.7111. In 2008, the minimum EIDL was 0.0222 and the maximum was 0.6333 . In 2009 , the minimum disclosure took the value of 0.1000 . The maximum disclosure value was 0.5444 . The result shows a positive trend in the disclosure during the period of study.

Table 4 presents the results of the CA contingency table that confirms the relevance of the power of a regulator on the disclosure level. In 2006, the highest number is in the 'bad' level. It was in that year that ANEEL issued the Resolution with guidelines for the preparation of a social and environmental report.

The concentration in the 'bad' level was reduced in 2007, when the power distribution companies began to disclosure the ANEEL socio and environment report, and 12 companies in the sample published the report using the GRI model. There were still 14 companies with poor level of disclosure in that year due to the fact that generation and transmission companies did not have regulations for disclosure and, although they had no impediment for voluntary disclosure in 2007, they only disclosed in 2008, according to ANEEL's rules. There is a significant increase in the 'regular', 'good' and 'very good' levels: 19, 13 and 14, respectively.

Table 4 Table of the contingence variable year vs. level of the disclosure in panel

\begin{tabular}{lccccc}
\hline & \multicolumn{5}{c}{ Environmental information disclosure level (EIDL) } \\
\cline { 2 - 6 } Year & Bad & Regular & Good & Very good & Active margin \\
\hline 2006 & 56 & 4 & 0 & 0 & 60 \\
2007 & 14 & 19 & 13 & 14 & 60 \\
2008 & 0 & 18 & 19 & 23 & 60 \\
2009 & 0 & 11 & 26 & 23 & 60 \\
Active margin & 70 & 52 & 58 & 60 & 240 \\
\hline
\end{tabular}

Source: Own computations

In 2008, generation and transmission companies published in accordance to ANEEL's guidance. Companies that fit into these two segments of the chain show the lowest levels of disclosure, including in the financial aspect, for that reason only 15 and 05 firms, respectively, were included in the sample. Despite this limitation, the level of environmental disclosure showed improvement because none of the companies fell in the 'bad' category and 42 firms were in the 'good' and 'very good' levels.

The 2009 result seems more satisfactory: 26 companies were classified in the 'good' disclosure level and 23 in the 'very good' level. 
In short, in terms of disclosure, the sample shows a balance in the categories 'regular', 'good' and 'very good', presenting a greater number of companies in 'bad' quality only in 2006.

This result is relevant because it aims to contribute to some studies conducted in Brazil that investigated several sectors with companies listed on Stock Exchange (BOVESPA), and show that the energy sector has a great level of disclosure when compared with other sectors (Borba, 2010; Braga et al., 2009; Calixto et al., 2007; Rover et al., 2005). In this study, which examines only the electricity sector and companies that are not listed on stock exchanges, results show that there is still much to improve on the level of disclosure of environmental information in this sector, both in qualitative and quantitative terms.

The above aspects can be seen on the perceptual map shown in Figure 3.

The placing of the variables' categories in the dimensions confirms that in 2006, a 'bad' level of disclosure was predominant.

In 2007, EIDL was near the 'regular' level and in 2008 the level of disclosure approaches 'very good'.

Finally, in 2009, the level of disclosure progresses, with emphasis in the 'good' level, which shows that seven companies went from 'regular' level to 'good', and the number of companies in the 'very good' level in 2008 remained the same. Therefore, the perceptual map confirms the evolution of EIDL in the period of study.

Figure 3 Perceptual map

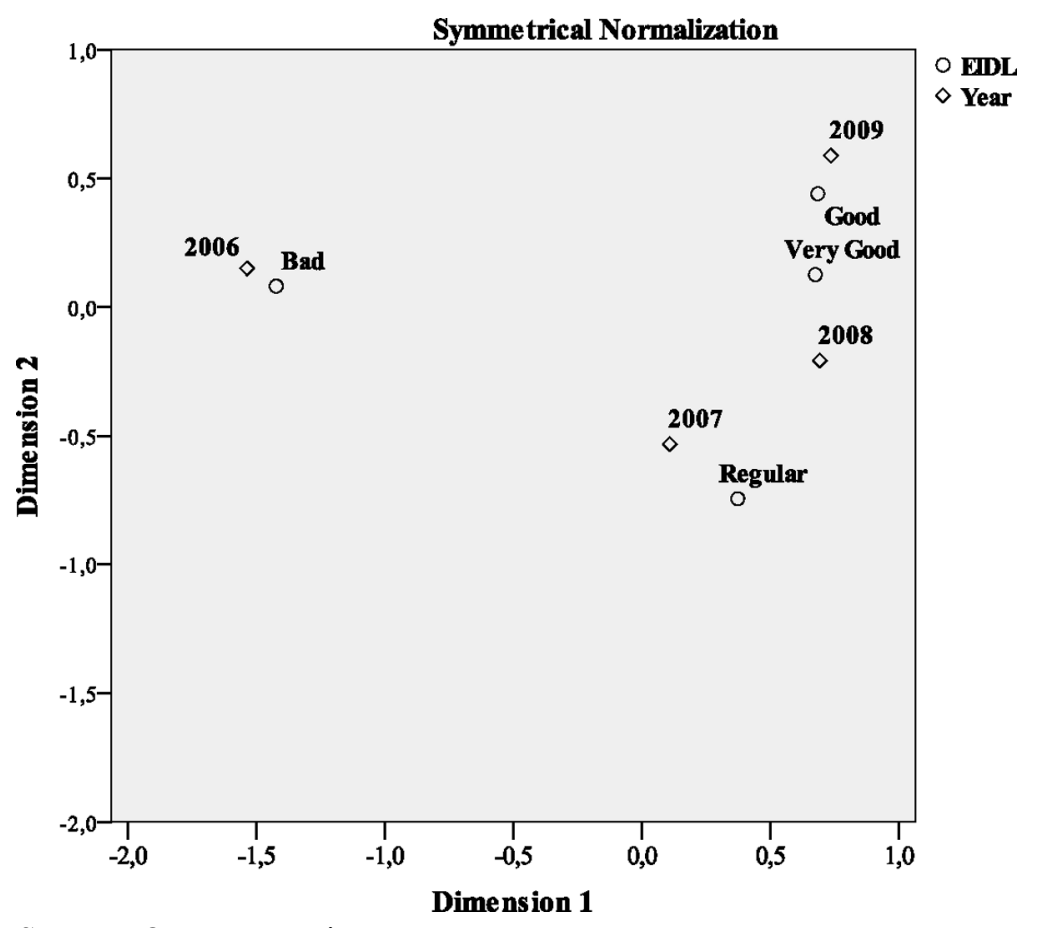

Source: Own computations 


\section{Conclusions}

National and international researches on the environmental disclosure level of enterprises from different sectors show that the electricity sector companies have optimal levels of disclosure, because it is considered a sensitive industry and it has large companies.

The main contribution of this research, by studying only the electricity sector in Brazil, is to show an approach to the level of environmental information disclosure of such companies in the context of the operational value chain and in the period of validity of ANEEL's guidelines for social and environmental disclosure. The pioneering aspect of the study is focused on the use of ANEEL's indicators for EIDL calculation, in association with the GRI indicators.

In this context, the main findings revealed in this study confirm the improvement in the level of environmental disclosure by companies in the electricity sector in the period 2006-2009.

The relationship between the variables year of publication and EIDL shows that in 2006, the 'bad' level of disclosure prevails, since only four companies made voluntary disclosure of GRI indicators. In 2007, the level was between 'regular' and 'good', indicating the important role of early regulation of ANEEL in social and environmental report for distributing companies.

In 2008, the 2007 level was maintained, with an approximation for the 'very good' category. Finally, in 2009, the level of disclosure progressed, with emphasis in the 'good' level. This demonstrates the evolution of companies in the collection and dissemination of environmental information in the reports, both in the GRI and the ANEEL models, and especially the prospect of consolidation of ANEEL's social and environmental report as an important tool to disseminate the environmental information in the electricity sector in Brazil.

The increased level of disclosure occurs as a result of ANEEL's social and environmental report publication. Therefore, the result reveals that the social and environmental reporting has become an important tool for environmental disclosure in the Brazilian electric power sector, notably for generation and transmission.

This disclosure improves the dialogue between companies and stakeholders and allows the improvement of environmental practices due to the exchange of experiences in the industry.

The expectation of the study is to contribute to the research on environmental disclosure, investigating a relevant sector for economic growth and social and global energy sustainability.

\section{Acknowledgements}

This study was funded by the Brazilian National Council for the Improvement of Higher Education (CAPES) and was partially supported by the Foundation for Science and Technology (FCT) under project grant PEst-C/EEI/UI0308/2011 and the National Electric Energy Agency (ANEEL). This work has been framed under the Initiative Energy for Sustainability of the University of Coimbra and supported by the Energy and Mobility for Sustainable Regions - EMSURE - Project (CENTRO-07-0224-FEDER002004). 


\section{References}

Aerts, W. and Cormier, D. (2009) 'Media legitimacy and corporate environmental communication', Accounting, Organizations and Society, Vol. 34, No. 1, pp.1-27.

Agência Nacional de Energia Elétrica (ANEEL) (2010) Relatórios ANEEL, http://www. aneel.gov.br

Bardin, L. (2008) Análise de Conteúdo, Edições 70 LDA, Lisboa.

Bolívar, M.P.R. (2009) 'Evaluating corporate environmental reporting on the internet: the utility and resource industries in Spain', Business \& Society, Vol. 48, pp.179-205.

Borba, J.A. (2010) 'Green reporting in Brazil: the case of industries sensitive to environment', $4^{a}$ GECAM - Conferência de Gestão e Contabilidade Ambiental, Leiria, Portugal, pp.14-15.

Braga, J.P., Oliveira, J.R.S. and Salotti, B.M. (2009) 'Determinantes do Nível de Divulgação Ambiental nas Demonstrações Contábeis de Empresas Brasileiras', Revista de Contabilidade da Universidade Federal da Bahia, Vol. 3, No. 3, pp.81-95.

Brammer, S. and Pavelin, S. (2006) 'Voluntary environmental disclosures by large UK companies', Journal of Business Finance \& Accounting, Vol. 33, Nos. 7-8, pp.1168-1188.

Brown, H.S., Jong, M. and Levy, D.L. (2009) 'Building institutions based on information disclosure: lessons from GRI's sustainability reporting', Journal of Cleaner Production, Vol. 17, pp.571-580.

Calixto, L., Barbosa, R.R. and Lima, M.B. (2007) 'The spread of voluntary environmental information: accounting reports versus internet', Revista de Contabilidade e Finanças, Edição 30 Anos de Doutorado, pp.84-95.

Campbell, D. (2004) 'A longitudinal and cross-sectional analysis of environmental disclosure in UK companies - a research note', The British Accounting Review, Vol. 36, pp.107-117.

Cho, C.H. and Patten, D.M. (2007) 'The role of environmental disclosures as tools of legitimacy: a research note', Accounting, Organizations and Society, Vol. 32, Nos. 7-8, pp.639-647.

Churchill Jr., G.A. (1986) 'A paradigm for developing better measures of marketing constructs', JMR, Journal of Marketing Research, Vol. 16, No. 1, ABI/INFORM Global, p.68.

Clarkson, P.M., Li, Y. and Richardson, G.D. and Vasvari, F.P. (2008) 'Revisiting the relation between environmental performance and environmental disclosure: an empirical analysis', Accounting, Organizations and Society, Vol. 33, pp.303-327.

Cormier, D. and Magnan, M. (2003) 'Environmental reporting management: a continental European perspective', Journal of Accounting and Public Policy, Vol. 22, pp.43-62.

Ernst \& Young and FIPECAFI (2009) Manual de Normas Internacionais de Contabilidade: IFRS versus Normas Brasileiras, São Paulo, Atlas.

ETHOS - Instituto Ethos (2010) Indicadores Ethos. http://www.ethos.org.br/index.php

Financial Accounting Standards Board (FASB) (1980) Qualitative Characteristics of Accounting Information, SFAC - Statement of Financial Accounting Concepts No. 2, USA.

Freeman, R.E. and Reed, D.L. (1983) 'Stockholders and stakeholders: a new perspective on corporate governance', Califórnia Management Review, Vol. 25, No. 3, pp.88-106.

Gallego, I. (2006) 'The use of economic, social and environmental indicators as a measure of sustainable development in Spain', Corporate Social Responsibility and Environmental Management, Vol. 13, pp.78-97.

García-Ayuso, M. and Larrinaga, C. (2003) 'Environmental disclosure in Spain: corporate characteristics and media exposure', Spanish Journal of Finance and Accounting, Vol. 115, pp.184-214.

García-Sánchez, I.M. (2008) 'Corporate social reporting: segmentation and characterization of Spanish companies', Corporate Social Responsibility and Environmental Management, Vol. 15, pp.187-198. 
Global Reporting Initiative (GRI) (2010) GRI Report List, http://www.globalreporting.org/ GRIReports/GRIReportsList/

Hair Jr., J.F., Anderson, R.E., Tatham, R.L. and Black, W.C. (2005) Análise Multivariada de Dados, Bookman, Porto Alegre.

Hendriksen, E.S. and Van Breda, M.F.V. (1992) Accounting Theory, McGraw-Hill, USA.

Holland, L. and Boon Foo, Y. (2003) 'Differences in environmental reporting practices in the UK and the US: the legal and regulatory context', The British Accounting Review, Vol. 35, pp.1-18.

Horngren, C.T., Foster, G. and Datar, S.M. (2000) Cost Accounting: A Managerial Emphasis, Prentice Hall, USA.

Hossain, M. and Hammami, H. (2009) 'Voluntary disclosure in the annual reports of an emerging country: the case of Qatar', Advances in Accounting, incorporating Advances in International Accounting, Vol. 25, pp.255-265.

Jose, A. and Lee, S. (2007) 'Environmental reporting of global corporations: a content analysis based on website disclosures', Journal of Business Ethics, Vol. 72, pp.307-321.

Liu, X. and Anbumozhi, V. (2009) 'Determinant factors of corporate environmental information disclosure: an empirical study of Chinese listed companies', Journal of Cleaner Production, Vol. 17, No. 6, pp.593-600.

Maroco, J. and Garcia-Marques, T. (2006) 'Qual a fiabilidade do alfa de Cronbach? Questões antigas e soluções modernas?', Laboratório de Psicologia, Vol. 4, No. 1, pp.65-90.

Moneva, J.M. and Llena, F. (2000) 'Environmental disclosures in the annual reports of large companies in Spain', European Accounting Review, Vol. 9, No. 1, pp.7-29.

Monteiro, S.S.M. and Aibar-Guzmán, B. (2010) 'Determinants of environmental disclosure in the annual reports of large companies operating in Portugal', Corporate Social Responsibility and Environmental Management, Vol. 17, pp.185-201.

Morhardt, J.E., Baird, S. and Freeman, K. (2002) 'Scoring corporate environmental and sustainability reports using GRI 2000, ISO 14031 and other criteria', Corporate Social Responsibility and Environmental Management, Vol. 9, pp.215-233.

Múrcia, F.D., Santos, A., Salotti, B.M. and Nascimento, A.R. (2008) 'Mapeamento da pesquisa sobre disclosure ambiental no cenário internacional: uma revisão dos artigos publicados em periódicos de língua inglesa no período de 1997-2007', $8^{\circ}$ Congresso USP de Contabilidade e Controladoria, São Paulo, Brasil.

Panayiotou, N.A., Aravossis, K.G. and Moschou, P. (2009) 'A new methodology approach for measuring corporate social responsibility performance', Water Air Soil Pollute: Focus, Vol. 9, pp.129-138.

Pestana, M.H. and Gageiro, J.N. (2008) Análise de Dados para Ciências Sociais - a complementariedade do SPSS, Sílabo, Lisboa.

Riahi-Belkaoui, A. (2004) Accounting Theory, Cengage Learning, USA.

Rover, S., Alves, J.L. and Borba, J.A. (2005) 'Análise do conteúdo ambiental das demonstrações contábeis publicadas no Brasil e nos Estados Unidos: um estudo nas companhias com ADR nível III', $5^{\circ}$ Congresso USP de Controladoria e Contabilidade, São Paulo, Brasil.

Rover, S., Tomazzia, E.C., Múrcia, F.D. and Borba, J.A. (2009) 'Explicações para a divulgação voluntária ambiental no Brasil utilizando análise de regressão em painel', III Congresso IAAER: ANPCont, São Paulo, Brasil.

Sangle, S. and Babu, P.R. (2007) 'Evaluating sustainability practices in terms of stakeholders satisfaction', International Journal Business Governance and Ethics, Vol. 3, No. 1, pp.56-76.

Schaltegger, S. and Burritt, R.L. (2009) 'Sustainability accounting for companies: Catchphrase or decision support for business leaders?', Journal of World Business, pp.1-10.

Simnett, R., Vanstraelen, A. and Chua, W.F. (2009) 'Assurance on sustainability reports: an international comparison', The Accounting Review, Vol. 84, pp.937-967. 
Skouloudis, A., Evangelinos, K. and Kourmousis, F. (2010) 'Assessing non-financial reports according to the Global Reporting Initiative guidelines: evidence from Greece', Journal of Cleaner Production, Vol. 18, pp.426-438.

United Nations (1987) Report of the World Commission on Environment and Development, http://ambiente.files.wordpress.com/2011/03/brundtland-report-our-common-future.pdf

\section{Nomenclature}

\begin{tabular}{ll}
\hline ANEEL & National Electric Energy Agency \\
BOVESPA & Bolsa de Valores de São Paulo \\
CA & Correspondence Analysis \\
CEMIG & Companhia Energética de Minas Gerais \\
CERES & Coalition for Environmentally Responsible Economics \\
CSR & Corporate Social Responsibility \\
CPFL & Companhia Paulista de Força e Luz \\
EIDL & Environmental Information Disclosure Level \\
FASB & Financial Accounting Standard Board \\
GRI & Global Reporting Initiative \\
IAS & International Accounting Standard \\
IASC & International Accounting Standard Committee \\
IBASE & Brazilian Institute of Social and Economic Analyses \\
ICC & International Chamber of Commerce Business Charter for Sustainable Development \\
ISO & International Standards Organisation's \\
NA & Not applicable \\
ND & Not available \\
NI & Not identified \\
NP & Unpublished \\
NGOs & Non-Governmental Organisations \\
PERI & Public Environmental Reporting Initiative \\
\hline
\end{tabular}

